\title{
Faktor-faktor yang Mempengaruhi Partisipasi Mahasiswa dalam Proses Tutorial pada Metode Belajar Problem-Based Learning (PBL) di Fakultas Kedokteran Universitas Riau
}

\author{
M. Yulis Hamidy ${ }^{1}$, Enikarmila Asni ${ }^{2}$
}

\begin{abstract}
Problem-based Learning (PBL) is an effective approach to promote student-centered learning. PBL tutorials were the key step in PBL process. Students' participation in PBL tutorials can be influenced by many factors. The aim of this study was to identify the factors that influence students' participation in PBL tutorials among students in Faculty of Medicine University of Riau. The research was a cross sectional study using self report questionnaires obtained from PBL students, conducted in April - October 2009. The students' participation was assessed using Visschers-Pleijers questionnaires. The result revealed the characteristics of parcipants which are female (79.5\%), 19 years old (40.2\%), had GPA $2.50-3.00(56.7 \%)$, had past experience in organization (89.0\%). Among $44.1 \%$ of the participants showed active participation in tutorial processs. Male students more likely active than female students $(\mathrm{P}=0.045)$. Another factors including age, GPA, past experience in organization, role of tutors, and quality of scenario were not influenced the participation of subject. Students' participation in PBL tutorials among students in Faculty of Medicine University of Riau was influenced by sex.
\end{abstract}

Keywords: students' participation, tutorial, problem-based learning, influencing factors

Fakultas Kedokteran Universitas Riau (FK Unri) telah mengimplementasikan Kurikulum Berbasis Kompetensi (KBK) mulai tahun 2007. Sebagai salah satu metode belajar yang digunakan dalam rangka implementasi KBK tersebut adalah metode Problem-based learning (PBL).

Problem-based Learning (PBL) merupakan suatu pendekatan yang efektif dalam student centred learning. Metode PBL mendorong mahasiswa untuk melakukan belajar mandiri, berpikir kritis, berpikir kreatif, belajar sepanjang hayat, bekerja sama, menganalisis suatu informasi, dan meningkatkan pemahaman terhadap suatu permasalahan. Berdasarkan permasalahan yang diberikan sebagai pemicu, mahasiswa dapat mengintegrasikan dan menerapkan pengetahuan yang dimilikinya. ${ }^{1,2}$

\footnotetext{
1 Penulis Untuk korespondensi: Alamat: Bagian Farmakologi Fakultas Kedokteran Universitas Riau Jalan Diponegoro No. 1 Pekanbaru, 28111 e-mail: yulis hamidy@yahoo.com

2 Bagian Biokimia, Fakultas Kedokteran, Universitas Riau, Jl. Diponegoro No. 1, Pekanbaru, Indonesia, 28111. Email : eni93@yahoo.com
}

Problem-based learning memberikan manfaat antara lain mahasiswa mempunyai peran aktif dalam proses belajar mengajar sehingga mereka mempunyai kemampuan untuk mendefinisikan suatu masalah, mengidentifikasi dan menyelesaikan masalah, memperoleh dan menginterpretasikan data, membuat perencanaan, serta mentransfer hasil pembelajarannya ke dalam kehidupan sehari-hari. Mahasiswa juga mempunyai kemampuan untuk menggabungkan aspek sosial dan etika ke dalam ilmu kedokteran, berkolaborasi dalam belajar, mempunyai sifat kepemimpinan, terampil dalam berkomunikasi dan berempati, serta dapat mengidentifikasi kekuatan dan kelemahan yang dimilikinya. $^{3}$

Metode PBL terdiri dari 2 sesi tutorial untuk membahas suatu skenario yang menjadi pemicu proses belajar. Diskusi tutorial dilaksanakan dua kali untuk setiap skenario yang diikuti oleh 10-12 orang mahasiswa untuk setiap kelompok dengan dipandu oleh seorang tutor sebagai fasilitator. Di antara 2 sesi tutorial tersebut mahasiswa mendapat masa 
tenggang untuk memperoleh kesempatan melaksanakan belajar mandiri. Waktu ini dapat dimanfaatkan oleh mahasiswa untuk mengembangkan kemampuannya mencari berbagai literatur yang diperlukan, menelaah secara kritis berbagai informasi yang didapatkan, dan berkonsultasi dengan para ahli. ${ }^{4}$

Tutorial dalam konteks PBL adalah suatu proses belajar aktif di dalam diskusi kelompok kecil yang distimulasi oleh suatu problem (skenario) dan bertujuan untuk mengaktifkan prior knowledge mahasiswa dengan difasilitasi oleh seorang tutor. Dalam proses tutorial terjadi komunikasi antarpersonal dan interaksi yang kompleks sehingga harus dikelola dengan baik. Setiap mahasiswa dituntut untuk berpartisipasi aktif sehingga dapat memberikan kontribusi yang merata serta saling melengkapi pengetahuan di antara mahasiswa mengenai permasalahan yang sedang dipelajari. Partisipasi mahasiswa dalam elaborasi dan kokonstruksi pengetahuan berkaitan dengan efektivitas tutorial PBL dan selanjutnya akan menentukan keberhasilan belajar. ${ }^{5,6}$

Tutorial adalah kunci keberhasilan metode PBL. Tutorial yang efektif akan menjamin pencapaian tujuan belajar. Pada tutorial yang efektif, diskusi kelompok berlangsung secara kooperatif dan bukannya secara kompetitif. Setiap mahasiswa harus berpartisipasi aktif, sebaliknya anggota kelompok yang dominan diminta untuk mengurangi dominasinya. Partisipasi mahasiswa dalam proses tutorial dapat dipengaruhi oleh beberapa faktor, antara lain karakteristik mahasiswa tersebut, kualitas skenario yang digunakan dan peranan tutor sebagai fasilitator. Apabila partisipasi mahasiswa dalam proses tutorial kurang, maka tutorial tidak akan efektif sehingga tujuan pembelajaran akan sulit dicapai. ${ }^{7}$ Oleh karena itu perlu diketahui faktorfaktor apa saja yang mempengaruhi partisipasi mahasiswa dalam proses tutorial yang telah dilaksanakan di FK Unri, sehingga dapat dilakukan upaya-upaya untuk meningkatkan partisipasi mahasiswa dalam proses tutorial.

Penelitian ini bertujuan untuk mengetahui faktor-faktor apa saja yang mempengaruhi partisipasi mahasiswa dalam proses tutorial pada metode belajar Problem-Based Learning (PBL) di Fakultas Kedokteran Universitas Riau.

\section{METODE}

Penelitian ini merupakan penelitian cross sectional untuk mengetahui faktor-faktor yang mempengaruhi partisipasi mahasiswa dalam proses tutorial pada metode PBL di FK Unri. Penelitian ini dilaksanakan di Fakultas Kedokteran Universitas Riau pada bulan April - Oktober 2009. Populasi penelitian adalah mahasiswa FK Unri yang mengikuti Kurikulum Berbasis Kompetensi (KBK) yang berjumlah 217 orang. Sampel penelitian adalah mahasiswa yang bersedia berpartisipasi dalam penelitian ini yang dinyatakan dengan penyetujuan informed consent.

Partisipasi mahasiswa dalam proses tutorial dinilai dengan menggunakan daftar tilik yang merupakan hasil modifikasi dari Visschers-Pleijers yang sudah divalidasi sebelumnya. ${ }^{6}$ Daftar tilik ini menilai partisipasi mahasiswa melalui tiga aspek yaitu partisipasi mahasiswa dalam mengeksplorasi pertanyaan, menjelaskan dan mendiskusikan konflik kognitif. Karakteristik mahasiswa yang diteliti adalah jenis kelamin, umur, asal SMA, Indeks Prestasi Kumulatif (IPK), dan pengalaman mengikuti organisasi. Peran tutor dinilai dengan menggunakan Teaching Style Inventory dari Kassab ${ }^{8}$ yang mencakup 4 aspek yaitu fasilitatif, kolaboratif, non asertif, dan non sugestif. Selanjutnya untuk kualitas skenario dinilai dengan menggunakan kriteria Nieminen yang meliputi apakah suatu skenario menarik atau tidak, mudah dimengerti, mendorong mahasiswa untuk belajar mandiri, membangkitkan rasa ingin tahu dan mendorong mahasiswa untuk berdiskusi. ${ }^{9}$

Data yang diperoleh diolah dan dianalisis dengan menggunakan program STATA 9.1. Faktorfaktor yang mempengaruhi partisipasi mahasiswa dalam proses tutorial dianalisis secara univariat kemudian dilanjutkan dengan analisis bivariat dan analisis multivariat.

\section{HASIL}

Dari 137 orang subjek penelitian yang menyatakan bersedia untuk mengikuti penelitian, seluruhnya mengisi dan mengembalikan kuesioner. Namun hanya 127 kuesioner yang memenuhi syarat untuk dilakukan analisis selanjutnya karena 10 kuesioner lainnya tidak diisi dengan lengkap. Karakteristik subjek penelitian dapat dilihat pada Tabel 1. 
JIK, Jilid 4, Nomor 1, Maret 2010, Hal. 30-35

Tabel 1. Karakteristik subjek penelitian

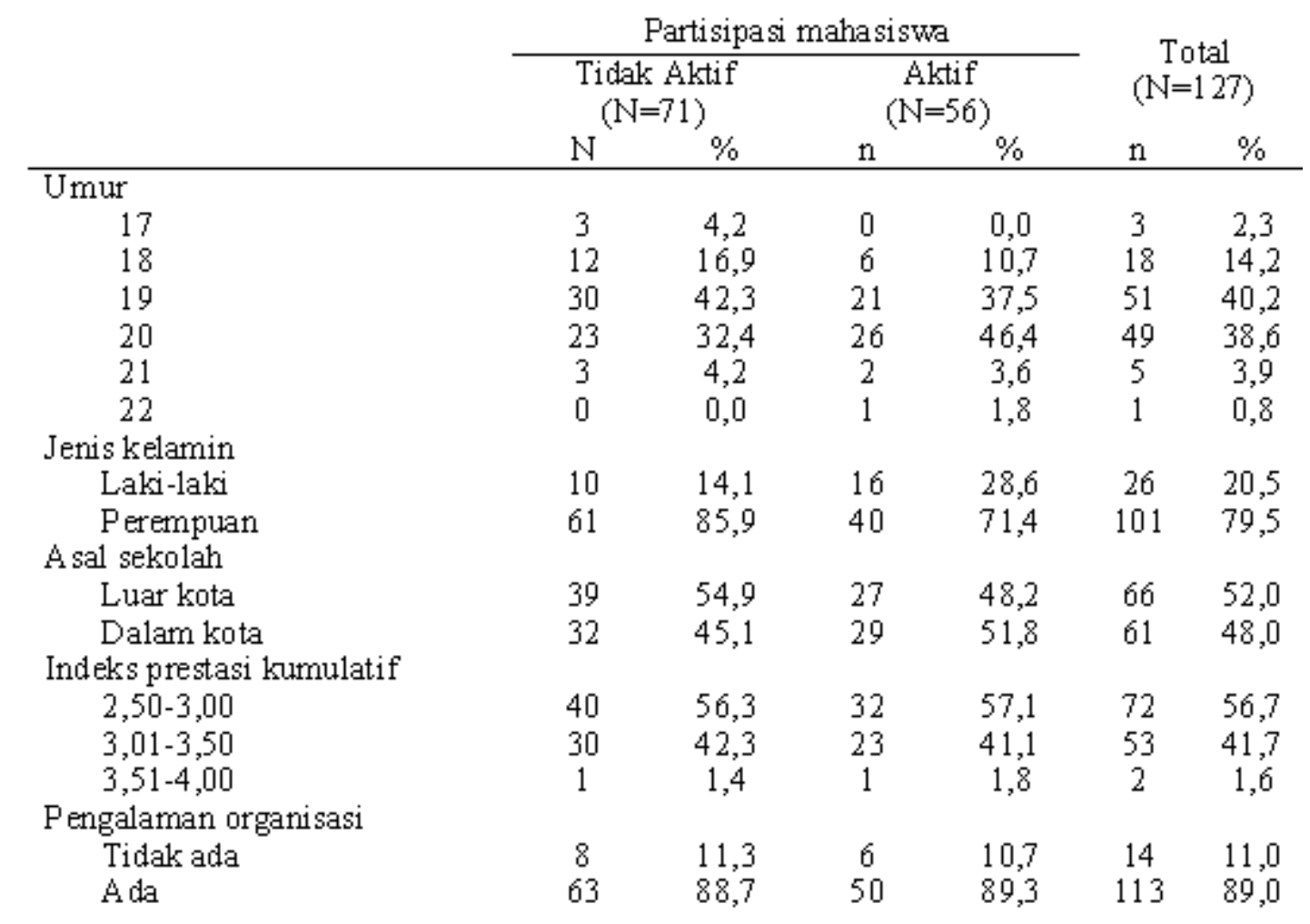

Tabel 1 menunjukkan bahwa sebagian besar subjek penelitian berumur 19-20 tahun, berjenis kelamin perempuan, mempunyai IPK antara 2,503,00 , dan telah mempunyai pengalaman dalam berorganisasi. Subjek penelitian yang berpartisipasi aktif dalam proses tutorial adalah sebanyak $44,1 \%$ (56/127).

Peran tutor dan kualitas skenario yang digunakan dalam proses tutorial yang dilaksanakan di FK Unri dapat dilihat pada tabel berikut ini.

Tabel 2. Peran tutor dan kualitas skenario

\begin{tabular}{|c|c|c|c|c|c|c|}
\hline & \multicolumn{4}{|c|}{ Partisipasi mahasiswa } & \multirow{2}{*}{\multicolumn{2}{|c|}{$\begin{array}{c}\text { Total } \\
(\mathrm{N}=127)\end{array}$}} \\
\hline & \multicolumn{2}{|c|}{$\begin{array}{c}\text { Tidak Aktif } \\
(\mathrm{N}=71)\end{array}$} & \multicolumn{2}{|c|}{$\begin{array}{c}\text { Aktif } \\
(\mathrm{N}=56)\end{array}$} & & \\
\hline & $\mathrm{N}$ & $\%$ & $\mathrm{n}$ & $\%$ & $\mathrm{n}$ & $\%$ \\
\hline \multicolumn{7}{|l|}{ Tutor fasilitatif } \\
\hline Tidak & 29 & 40,9 & 23 & 41,1 & 52 & 40,9 \\
\hline$Y a$ & 42 & 59,1 & 33 & 58,9 & 75 & 59,1 \\
\hline \multicolumn{7}{|c|}{ Tutor kolaboratif } \\
\hline Tidak & 5 & 7,0 & 4 & 7,1 & 9 & 7,1 \\
\hline$Y a$ & 66 & 93,0 & 52 & 92,9 & 118 & 92,9 \\
\hline \multicolumn{7}{|l|}{ Tutor nonasertif } \\
\hline Tidak & 26 & 36,6 & 23 & 41,1 & 49 & 38,6 \\
\hline$Y a$ & 45 & 63,4 & 33 & 58,9 & 78 & 61,4 \\
\hline \multicolumn{7}{|l|}{ Tutor sugestif } \\
\hline Tidak & 40 & 56,3 & 37 & 66,1 & 77 & 60,6 \\
\hline $\mathrm{Ya}$ & 31 & 43,7 & 19 & 33,9 & 50 & 39,4 \\
\hline \multicolumn{7}{|c|}{ Kualitas skenario } \\
\hline Tidak baik & 12 & 16,9 & 7 & 12,5 & 19 & 15,0 \\
\hline B aik & 59 & 83,1 & 49 & 87,5 & 108 & 85,0 \\
\hline
\end{tabular}


Tabel 2 menunjukkan bahwa sebagian besar tutor bersifat fasilitatif, kolaboratif dan nonasertif. Dari data ini juga terlihat bahwa ternyata sebagian besar tutor tidak bersifat sugestif. Skenario yang digunakan dalam proses tutorial sebagian besar baik.

Beberapa karakteristik subjek penelitian dan partisipasi mahasiswa dalam proses tutorial dapat dilihat pada Tabel 3 berikut ini.

Tabel 3. Beberapa karakteristik subjek penelitian dan partisipasi mahasiswa

\begin{tabular}{|c|c|c|c|c|c|c|}
\hline & \multicolumn{4}{|c|}{ Partisipasi mahasiswa } & \multirow{3}{*}{$\mathrm{RP}$} & \multirow{3}{*}{$P$} \\
\hline & \multicolumn{2}{|c|}{$\begin{array}{l}\text { Tidak Aktif } \\
(\mathrm{N}=71)\end{array}$} & \multicolumn{2}{|c|}{$\begin{array}{c}\text { Aktif } \\
(\mathrm{N}=56)\end{array}$} & & \\
\hline & $\mathrm{n}$ & $\%$ & $\mathrm{~N}$ & $\%$ & & \\
\hline \multicolumn{7}{|l|}{ Jenis kelamin } \\
\hline Laki-laki & 10 & 14,1 & 16 & 28,6 & & \\
\hline Perempuan & 61 & 85,9 & 40 & 71,4 & 0,48 & 0,045 \\
\hline \multicolumn{7}{|l|}{ Asal sekolah } \\
\hline Luar kota & 39 & 54,9 & 27 & 48,2 & & \\
\hline Dalam kota & 32 & 45,1 & 29 & 51,8 & 1,15 & 0,452 \\
\hline \multicolumn{7}{|c|}{ Pengalaman organisasi } \\
\hline Tidak ada & 8 & 11,3 & 6 & 10,7 & & \\
\hline Ada & 63 & 88,7 & 50 & 89,3 & 1,00 & 0,921 \\
\hline
\end{tabular}

Tabel 3 memperlihatkan hasil analisis bivariat terhadap beberapa karakteristik subjek penelitian dan partisipasi mahasiswa. Subjek penelitian yang berjenis kelamin laki-laki lebih berpartisipasi aktif daripada perempuan, sedangkan asal sekolah dan pengalaman organisasi tidak mempunyai pengaruh terhadap partisipasi mahasiswa dalam proses tutorial.

Hasil analisis bivariat terhadap pengaruh tutor dan skenario terhadap partisipasi mahasiswa dapat dilihat pada Tabel 4 berikut ini.

Tabel 4. Pengaruh tutor dan skenario terhadap partisipasi mahasiswa

\begin{tabular}{|c|c|c|c|c|c|c|}
\hline & \multicolumn{4}{|c|}{ Partisipasi mahasiswa } & \multirow{3}{*}{$\mathrm{RP}$} & \multirow{3}{*}{$\mathrm{P}$} \\
\hline & \multicolumn{2}{|c|}{$\begin{array}{l}\text { Tidak Aktif } \\
\quad(\mathrm{N}=71)\end{array}$} & \multicolumn{2}{|c|}{$\begin{array}{c}\text { Aktif } \\
(\mathrm{N}=56)\end{array}$} & & \\
\hline & $\mathrm{n}$ & $\%$ & $\mathrm{~N}$ & $\%$ & & \\
\hline \multicolumn{7}{|l|}{ Tutor fasilitatif } \\
\hline Tidak & 29 & 40,9 & 23 & 41,1 & & \\
\hline $\mathrm{Ya}$ & 42 & 59,1 & 33 & 58,9 & 1,00 & 0,979 \\
\hline \multicolumn{7}{|l|}{ Tutor kol aboratif } \\
\hline Tidak & 5 & 7,0 & 4 & 7,1 & & \\
\hline $\mathrm{Ya}$ & 66 & 93,0 & 52 & 92,9 & 1,00 & 0,982 \\
\hline \multicolumn{7}{|l|}{ Tutor nonasertif } \\
\hline Tidak & 26 & 36,6 & 23 & 41,1 & & \\
\hline Ya & 45 & 63,4 & 33 & 58,9 & 0,90 & 0,609 \\
\hline \multicolumn{7}{|l|}{ Tutor sugestif } \\
\hline Tidak & 40 & 56,3 & 37 & 66,1 & & \\
\hline Ya & 31 & 43,7 & 19 & 33,9 & 0,85 & 0,265 \\
\hline \multicolumn{7}{|l|}{ Kualitas skenario } \\
\hline Tidak baik & 12 & 16,9 & 7 & 12,5 & & \\
\hline Baik & 59 & 83,1 & 49 & 87,5 & 1,31 & 0,490 \\
\hline
\end{tabular}


Tabel 4 menunjukkan bahwa tutor tidak mempunyai pengaruh terhadap partisipasi mahasiswa, sedangkan skenario yang baik meskipun dapat meningkatkan partisipasi aktif mahasiswa sebesar 1,3 kali namun pengaruhnya ternyata tidak bermakna $(\mathrm{p}=0,490)$.

Pada analisis bivariat ini terlihat bahwa jenis kelamin adalah satu-satunya faktor yang berpengaruh terhadap partisipasi mahasiswa dalam proses tutorial. Karena hanya ada satu faktor yang berpengaruh maka analisis tidak dapat dilanjutkan ke analisis multivariat.

\section{PEMBAHASAN}

Beberapa keterbatasan harus dipertimbangkan dalam menginterpretasikan hasil penelitian ini. Instrumen penelitian yang digunakan untuk menilai partisipasi mahasiswa dalam proses tutorial adalah daftar tilik yang merupakan hasil modifikasi dari Visschers-Pleijers. Peran tutor dinilai dengan menggunakan Teaching Style Inventory dari Kassab dan untuk kualitas skenario dinilai dengan menggunakan kriteria Nieminen. Instrumeninstrumen ini adalah instrumen yang lazim digunakan di luar negeri, sehingga perlu dipertimbangkan untuk mengembangkan instrumen yang benar-benar sesuai untuk kondisi di Indonesia. Untuk meminimalisir bias akibat instrumen maka instrumen tersebut terlebih dahulu divalidasi melalui penelitian yang dilakukan oleh Rachmi di Fakultas Kedokteran Universitas Mulawarman Samarinda.

Persepsi mahasiswa terhadap peran tutor dan kualitas skenario juga tidak sama, untuk itu sebelum mengisi kuesioner terlebih dahulu diberikan penjelasan kepada mahasiswa tentang peran tutor dan skenario dalam proses tutorial. Penilaian mahasiswa terhadap tutor di kelompoknya masingmasing memungkinkan terjadinya bias dalam penilaian karena tutor yang dinilai berbeda-beda. Dengan adanya keterbatasan ini maka hasil yang diperoleh tidak dapat digeneralisasikan untuk fakultas kedokteran lainnya.

Hasil penelitian ini menunjukkan bahwa satusatunya faktor yang berhubungan dengan partisipasi mahasiswa dalam proses tutorial adalah jenis kelamin. Pada penelitian ini terlihat bahwa subjek laki-laki cenderung lebih aktif jika dibandingkan dengan subjek perempuan. Hasil yang sama juga didapatkan oleh Levy \& Merchant, ${ }^{10}$ yang meneliti pengaruh gender terhadap keterampilan belajar mahasiswa. Hal ini disebabkan secara psikologis dan fisik laki-laki lebih aktif daripada perempuan. ${ }^{11}$

Indeks prestasi kumulatif tidak mempunyai pengaruh terhadap partisipasi subjek dalam tutorial. Hal ini disebabkan karena pada penelitian ini subjek yang digunakan duduk di semester II-IV, sehingga pengaruh IPK belum dapat dilihat.

Partisipasi subjek dalam proses tutorial pada penelitian ini tidak dipengaruhi oleh asal sekolah. Tidak ada perbedaan partisipasi mahasiswa dalam proses tutorial pada subjek yang berasal dari sekolah di dalam kota dengan sekolah di luar kota. Secara teoritis partisipasi mahasiswa dipengaruhi oleh pengalaman belajar mereka sebelumnya, ${ }^{12,13}$ sehingga perbedaan pengalaman belajar sewaktu di SMA akan mempengaruhi partisipasi mahasiswa. Sekolah yang berada di dalam kota mempunyai fasilitas yang lebih baik jika dibandingkan dengan sekolah yang berada di luar kota. Kondisi ini akan menyebabkan perbedaan aktivitas mahasiswa yang berasal dari sekolah di dalam kota dengan mahasiswa yang berasal dari sekolah di luar kota. Tidak berbedanya kesiapan belajar mandiri pada subjek yang berasal dari sekolah di dalam kota dengan sekolah di luar kota pada penelitian ini disebabkan karena subjek penelitian adalah mahasiswa yang duduk pada semester II-IV sehingga pengaruh asal sekolah sudah tidak dapat dilihat lagi.

Pengalaman organisasi merupakan faktor yang berpengaruh terhadap partisipasi aktif mahasiswa. Organisasi merupakan wadah bagi mahasiswa untuk mengungkapkan ide-ide kritis dan wadah untuk mengaktualisasikan dirinya. ${ }^{13}$ Pada penelitian ini tidak terlihat pengaruh pengalaman dalam berorganisasi terhadap partisipasi mahasiswa dalam proses tutorial. Hal ini disebabkan karena organisasi yang diikuti oleh mahasiswa tersebut tidak merangsang aktualisasi dirinya dan umumnya subjek hanya berperan secara pasif dalam keanggotaan organisasi yang diikutinya.

Tutor dan skenario juga tidak menunjukkan pengaruh terhadap partisipasi mahasiswa. Hal ini disebabkan karena tutor yang terlibat dalam proses tutorial sudah mengikuti pelatihan sebagai tutor terlebih dahulu, sehingga umumnya tutor yang ada 
di FK Unri mempunyai kemampuan yang relatif sama. Begitu juga dengan skenario yang digunakan dalam proses tutorial disusun berdasarkan pedoman yang sudah baku, sehingga skenario yang digunakan di FK Unri tidak lagi menjadi faktor yang mempengaruhi partisipasi mahasiswa.

\section{KESIMPULAN}

Dari penelitian ini dapat disimpulkan bahwa mahasiswa FK Unri yang berpartisipasi aktif dalam proses tutorial adalah sebanyak $44,1 \%$. Tutor dan skenario yang digunakan dalam proses tutorial sudah baik, sehingga kedua faktor ini tidak berpengaruh terhadap partisipasi mahasiswa. Partisipasi mahasiswa dalam proses tutorial di Fakultas Kedokteran Universitas Riau dipengaruhi oleh jenis kelamin mahasiswa.

\section{UCAPAN TERIMA KASIH}

Peneliti menyampaikan ucapan terima kasih kepada Lembaga Penelitian Universitas Riau yang telah mendanai penelitian ini dan kepada Dekan Fakultas Kedokteran Universitas Riau yang telah membantu terlaksananya penelitian ini.

\section{DAFTAR PUSTAKA}

1. Harden RM, Sowden S, Dunn WR. Educational strategies in curriculum development: SPICES model. Medical Education 1984; 1:284-97.

2. Sefton A. Problem based learning. In: Dent JA, Harden RM, editors. A practical guide for medical teachers. Oxford: Elsevier;2005. p.14350 .

3. Albanese MA, Mitchell S. Problem based learning: a review of literature on its outcomes and implementation issues. Academic Medicine $1993 ; 68: 52-81$.
4. Davis MH, Harden RM. AMEE Medical Education Guide No. 15: Problem-based learning: a practical guide. Medical Teacher 1999; 21(2), 130-40.

5. Wood DF. ABC of learning and teaching in medicine: Problem based learning. BMJ 2003; 326: 328-30.

6. Visschers-Pleijers AJSF, Dolmans DHJM, Wolfhagen IHAP, Van Der Leuten APM. Development and validation of a questionnaire to identify learning oriented group interaction in PBL. Medical Teacher 2005; 27(4):375-81.

7. Valle R, Petra I, Marinez-Gonzalez A, RojasRamirez JA, Morales LA, Pina GB. Assessment of student performance in problem based learning tutorial session. Medical Education 1998; 33(11): 818-22.

8. Kassab S, AlShboul Q. Teaching styles of tutors in a problem-based curriculum: students and tutors perception. Medical Teacher 2006; 28(5):460-4.

9. Nieminen J, Sauri P, Lonka K. On the relationship between grup functioning and study success in problem-based learning. Medical Education 2006; 40:64-71.

10.Levy BT, Merchant ML. Factors associated with higher clinical skills experience of medical students on a family medicine preceptorship. Fam Med. 2005; 37:332-40.

11. May R. The Art of Counseling. Oxford: Elsevier; 2003.

12. Mezirow J. A critical theory of adult learning and education. Adult Education 1981;32:3-24.

13.Hiemstra R. Self-directed learning: Individualizing instruction. In: Long HB, editor. Self-directed learning: Application \& theory. Georgia: Allyn and Bacon;1988. p.99-124. 